Abstracted/indexed in Academic Search Complete, Asia Journals Online, Bangladesh Journals Online, Biological Abstracts, BIOSIS Previews, CAB Abstracts, Current Abstracts, Directory of Open Access Journals, EMBASE/Excerpta Medica, Google Scholar, HINARI (WHO), International Pharmaceutical Abstracts, Open J-gate, Science Citation Index Expanded, SCOPUS and Social Sciences Citation Index;

ISSN: $1991-0088$

\title{
Effect of ascorbic acid on reduced glutathione level in arsenic- loaded isolated liver tissues of rat
}

\section{Beauty Saha}

Department of Pharmacology, Bangabnadhu Sheikh Mujib Medical University, Shahbag, Dhaka, Bangladesh.

\begin{tabular}{|c|c|}
\hline Article Info & \\
\hline Received: & 18 October 2006 \\
\hline Accepted: & 11 November 2006 \\
\hline Available Online: & 3 January 2008 \\
\hline DOI: $10.3329 /$ bjp.v & $1 \mathrm{i} 2.491$ \\
\hline Cite this article: & \\
\hline $\begin{array}{l}\text { Saha B. Effect of a } \\
\text { duced glutathione } \\
\text { loaded isolated li } \\
\text { Bangladesh J Phar } \\
71 .\end{array}$ & $\begin{array}{l}\text { ascorbic acid on re- } \\
\text { e level in arsenic- } \\
\text { iver tissues of rat. } \\
\text { rmacol. 2006; 1: 68- }\end{array}$ \\
\hline
\end{tabular}

\begin{abstract}
Isolated liver tissues of rat were loaded with trivalent arsenic and were exposed in presence and absence of ascorbic acid. The amount of reduced glutathione (GSH) in normal liver tissue was $52.0 \pm 0.2 \mathrm{mg} / \mathrm{g}$ protein. Addition of arsenic to the tissues reduced the amount of GSH to $11.5 \pm 0.3$ $\mathrm{mg} / \mathrm{g}$ protein. But when the arsenic loaded liver tissues were incubated with ascorbic acid at the concentration of $20 \mathrm{mg} / \mathrm{mL}$, the amount of GSH was 14.2 $\pm 0.1 \mathrm{mg} / \mathrm{g}$ protein. There was $22.6 \%$ increase of GSH level which was statistically significant $(\mathrm{p}<0.001)$ when compared with arsenic alone. This study suggests that ascorbic acid increased the GSH level in arsenic-treated rat's liver.
\end{abstract}

\section{Introduction}

Inorganic arsenic contamination of drinking water is found in Bangladesh. The source of arsenic in drinking water is the earth's crust where arsenic occurs naturally; industrial source $\mathrm{s}$ are also important in man made pollution. In Bangladesh, arsenic concentration in drinking water are alarmingly high than the standard set by World Health Organization (WHO) which is 10 $\mathrm{mg} / \mathrm{l}$. about $90 \%$ of the tube well providing $97 \%$ of the countries drinking water supply were found to contain unacceptable levels of arsenic ranging from 50-3000 $\mathrm{mg} / \mathrm{L}$ in 61 out of 64 districts of Bangladesh, water samples were found to have arsenic above $50 \mathrm{mg} / \mathrm{L}$, the maximum permissible limit recommended by WHO. About 57 million people of Bangladesh are exposed to harmful concentration of arsenic through drinking water. More than 40,000 patients of chronic arsenic poisoning are identified. Together with poverty and poor nutritional status of the population, chronic arsenic exposure to arsenic in drinking water is causing wide spread health hazard in Bangladesh (Rabbani et al., 2002).
There is no specific drug in the treatment of chronic arsenic poisoning (Khan et al., 1997; WHO, 2003). There remains some controversy in the use of chelating agents such as penicillamine, 2,3-dimercaptopropane sulphonate sodium (DMPS) and meso-2,3-dimercaptosuccinic acid (DMSA) in the treatment of chronic arsenic poisoning (WHO, 1997). These are not easily available in our country, costly and too toxic for administration. The main mechanism of arsenic toxicity is the inhibitory effects on cellular respiration at the level of mitochondria. Exposure of cells to arsenicals cause oxidative damage to essential proteins perhaps secondary to uncoupling or disruption of mitochondrial oxidative phosphorylation and increased production of hydrogen peroxide and subsequent production of reactive oxygen species (Barchowsky et al., 1999). These reactive species produced by endothelial cells after arsenic exposure stimulate cell signaling and activate transcription factors.

In health, there is a balance between free radical production and an endogenous anti-oxidative defense in the body. If the free radical production is very high 
overwhelming the endogenous defense of the body toxic injury to cells increases, known as endogenous anti-oxidant acts as a reducing agent for arsenic during biotransformation. Maintenance of normal glutathione concentration is necessary for continuation of this biotransformation mechanism. Not only for biotransformation of arsenic, glutathione is also necessary to detoxify free radicals and therefore, necessary to decrease the free radical-induced lipid peroxidation. In addition to converting hydrogen peroxide to water and oxygen, the remarkable property of GSH lies in its ability to destroy the radical nature of lipid peroxide by transforming it into the hydroxyl fatty acids (PUFA-OH). The selenium dependent glutathione peroxidase first converts reduced glutathione (GSH) to oxidized glutathione (GSSG) at the expense of hydrogen peroxide (Rabbani et al., 2002).

Various nutrients and vitamins can support the body's defense system to neutralize the toxic substances. Ascorbic acid is a natural anti-oxidant and water soluble, which can suppress free radical formation in the body. It also protects tissue and blood components. Antioxidant plays an important role in preventing free radical mediated damages by directly scavenging those (Ramanathan et al., 2002). Ascorbic acid can restore the anti-oxidant propery of oxidized tocopherol, suggesting that a major function of ascorbic acid is to recycle the tocopheroxyl radical (Ramanathan et al., 2002).

Availability of appropriate levels of anti-oxidants may help in the overall balance of the degenerative effects and the survival mechanism (Chattopadhyay et al., 2002). Arsenic administration significantly increased the serum TBARs, nitric oxide and decreased the whole blood GSH levels in rabbits indicating oxidative stress in vivo. Ascorbic acid, a-tocopherol, $\beta$-carotene are more effective in increasing the GSH of intoxicated rabbits as compared to placebo indicating its arsenic detoxification properties. The protective effects of antioxidant vitamins on the activities of glutathione cycle enzymes were observed in chicken (Ozturk-Ureket et al., 2001).

Ascorbic acid is easily available in foodstuff and cheap. It is present in citrus fruits, tomatoes, and green leafy vegetables. Ascorbic acid may be clinically useful to treat patients with arsenic toxicity. The aim of the present study was to see the effect of ascorbic acid on GSH level in arsenic-loaded isolated liver tissues of rat.

\section{Materials and Methods}

\section{Chemicals}

Arsenic trioxide was purchased from BDH. DTMB (5,5dithiol-2-nitrobenzoic acid), glutasthione and ascorbic acid were obtained from Sigma Chemicals, USA.

\section{Isolation of liver tissues}

The study was carried out on isolated liver tissues of Long Evans Norwegian adult healthy male rats weighing 160-200 g obtained from the animal house. The rats were housed in standard plastic cages with a light/dark cycle 12/12 hours at room temperature in a well-ventilated room. Rats were sacrificed under chloroform anesthesia. By giving a midline incision, abdomen was opened and the liver was taken out and it was immerged immediately in a beaker containing modified Tyrode solution, which was placed in the ice bath. It was then placed in a petri dish containing Tyrode solution and chopped into small pieces approximately $2 \times 2 \times 2 \mathrm{~mm}$ size. Each tube contained 10-12 small pieces of liver in presence of Tyrode solution and loaded with arsenic. Arsenic loaded tissues was then incubated in presence or absence of ascorbic acid at $37^{\circ} \mathrm{C}$. The reaction was stopped by immersing the test tube into $0-4^{\circ} \mathrm{C}$. Tissues were then homogenized by a hand homogenizer and estimated the amount of GSH using the method described by Beulter et al. (1963).

\section{Statistical analysis}

Data were analyzed using unpaired Students' t-test. The level of significance was set at $p$ value of 0.05 to 0.001 .

\section{Results}

The effect of different concentrations of ascorbic acid on GSH level in arsenic loaded isolated liver tissues of rat were shown in Table I. The amount of GSH in normal liver tissue was $52.0 \pm 0.2 \mathrm{mg} / \mathrm{g}$ protein. Addition of arsenic to the tissues reduced the amount of GSH to $11.5 \pm 0.3 \mathrm{mg} / \mathrm{g}$ protein. That is, arsenic caused $77.7 \%$ reduction of GSH level. But when the arsenic loaded liver tissues were incubated with ascorbic acid at the concentration of $20 \mathrm{mg} / \mathrm{mL}$, the amount of GSH was $14.2 \pm 0.1 \mathrm{mg} / \mathrm{g}$ protein. There was $23.5 \%$ increase of GSH level which was statistically significant $(\mathrm{p}<0.001)$ when compared with arsenic alone. Ascorbic acid at concentration of $200 \mathrm{mg} / \mathrm{mL}$ increased the amount of GSH to $20.9 \pm 0.1 \mathrm{mg} / \mathrm{g}$ protein. That is, there was $80.5 \%$ increase of GSH level. Two milligram of ascorbic acid per milliliter increased the GSH level to $26.8 \pm 0.2$ $\mathrm{mg} / \mathrm{g}$ protein.

Next the time course of the effect of ascorbic acid on GSH level in arsenic loaded liver tissues of rat was studied (Figure 1). The concentration of ascorbic acid used was $2 \mathrm{mg} / \mathrm{mL}$ and liver tissues were incubated for different periods. The amount of GSH in arsenic untreated tissues was $54.2 \pm 0.3 \mathrm{mg} / \mathrm{g}$ protein. After 20, 40,60 and $80 \mathrm{~min}$ incubation of arsenic loaded tissues, the amount of GSH were 12.9 $\pm 0.4,10.9 \pm 0.4,8.2 \pm 0.1$, $7.5 \pm 0.3 \mathrm{mg} / \mathrm{g}$ protein. But in presence of ascorbic acid 
Table I

Effect of different concentrations of ascorbic acid on GSH level in arsenic loaded liver tissues

\begin{tabular}{|lccc|}
\hline First incubation $(40 \mathrm{~min})$ & Second incubation $(40 \mathrm{~min})$ & Amount of GSH $(\mathrm{mg} / \mathrm{g}$ protein) & \%Increased \\
\hline Arsenic $(100 \mathrm{mg} / \mathrm{mL})$ & None & $11.5 \pm 0.3$ & - \\
& Ascorbic acid $(20 \mathrm{mg} / \mathrm{mL})$ & $14.2 \pm 0.1$ & 22.6 \\
& Ascorbic acid $(200 \mathrm{mg} / \mathrm{mL})$ & $20.9 \pm 0.1$ & 80.5 \\
& Ascorbic acid $(2 \mathrm{mg} / \mathrm{mL})$ & $26.8 \pm 0.2$ & 131.8 \\
\hline
\end{tabular}

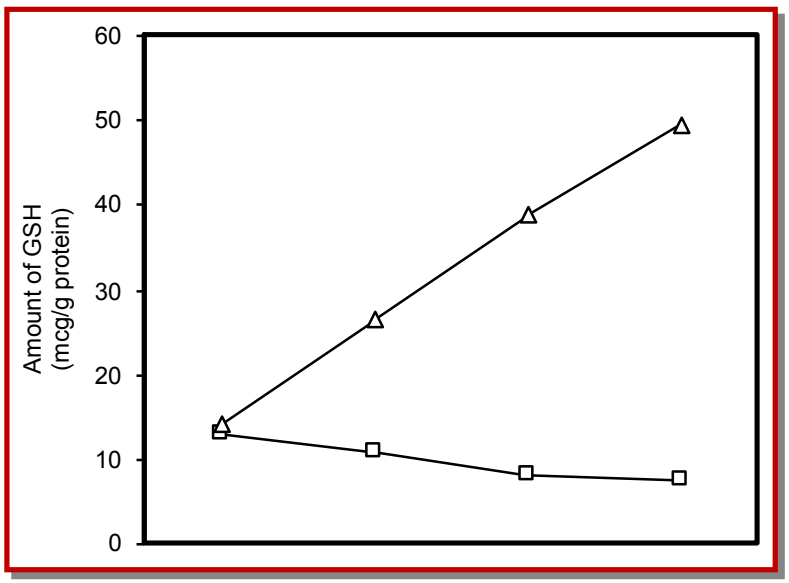

Figure 1: Time course of the effect of ascorbic acid on GSH level in arsenic loaded liver tissues

the amount of GSH were $14.1 \pm 0.1,26.5 \pm 0.1,39.0 \pm 0.1$ and $49.4 \pm 0.1 \mathrm{mg} / \mathrm{g}$ protein after $20,40,60$ and 80 minutes incubation of arsenic loaded tissue. The amount of GSH increased linearly up to $80 \mathrm{~min}$ of incubation.

\section{Discussion}

Results of the present study showed that GSH level decreased in arsenic loaded isolated rat liver tissues could be reversed by addition of ascorbic acid. The effect of ascorbic acid was both dose- and timedependent. In this study ascorbic acid was used at concentrations of 20,200 and $2000 \mu \mathrm{g}$. It was found that GSH level increased linearly even at concentrations of 2 $\mathrm{mg}$. Arsenic intoxication of rabbits significantly reduced the blood GSH level (Rabbani et al., 2002). It also inhibits the enzyme that catalyze GSH synthesis such as gluthatione reductase (Styblo and Thomas, 1995). The recovery of the depleted GSH was significantly greater in presence of vitamins such as $\beta$-carotene, ascorbic acid, a-tocopherol (Rabbani et al., 2002). Rats exposed to arsenic showed increased generation of nitric oxide and reactive oxygen species (ROS), loss of glutathione content, increase in lipid peroxidation and decrease superoxide dismutase (Chattopadhyay et al., 2002; Shi et al., 2004). The administration of ascorbic acid or a- tocopherol showed partial reversal of the effects indication possible protection from arsenic toxicity.

Ascorbic acid is a major anti-oxidant and water soluble. It neutralizes the toxicity and enhances the antioxidative system. It protects cells from free radical in the body. Ascorbic acid and GSH are among the most active reducing substances in living tissues. Both of these chemicals undergo redox cycling in vivo, and there seems to be a significant interrelationship in this cycling. For example, the toxic effects of GSH deficiency can be prevented by administrating ascorbic acid, indicating that ascorbic acid has a sparing effect on GSH (Meister, 1994).

The mechanism of excretion of arsenic depends on the presence of anti-oxidants and thiols that aid arsenic methylation and both arsenic and cadmium metallothionein binding (Patrick, 2003).

\section{Conclusion}

This study may give an evidence that ascorbic acid may be used for the treatment of chronic arsenic poisoning in order to increase the anti-oxidant effect which reduced following arsenic exposure.

\section{Acknowledgement}

I am grateful to Prof. Mir Misbahuddin, Department of Pharmacology, Bangabandhu Sheikh Mujib Medical University, Shahbag, Dhaka, Bangladesh for his guidance due the study.

\section{References}

Chattopadhyay S, Bhaumik S, Purkayastha M, Basu S, Chaudhuri AN, Gupta SD. Apoptosis and necrosis in developing brain cells due to arsenic toxicity and protection with anti-oxidants. Toxicol Lett. 2002; 136: 65-76.

Meister A. Glutathione-ascorbic acid anti-oxidant system in animals. J Biol Chem. 1994; 269: 9397-100.

Patrick L. Toxic metals and anti-oxidants. Altern Med Rev. 2003; 8: 106-28. 
Rabbani GH, Saha SK, Marni F, Akhtar M, Alauddin M, Mitra AK, Nasir M, Chowdhury AKA. Anti-oxidants in detoxification of arsenic-induced oxidative injury in rabbits. Bangladesh Arsenic Control Society, Dhaka, 2002, pp 69-77.

Shi H, Shi X, Liu KJ. Oxidative mechanism of arsenic toxicity and carcinogenesis. Mol Cell Biochem. 2004; 255: 67-78.

Styblo M, Thomas DJ. In vitro inhibition of glutathione reductase by arsenotriglutathione. Biochem Pharmacol. 1995; 49: 971-07. 